\title{
ARTICLE
}

Received 26 Mar 2013 | Accepted 19 Jun 2013 | Published 19 Jul $2013 \quad$ DOl: 10.1038/ncomms3178

\section{A green lead hydrometallurgical process based on a hydrogen-lead oxide fuel cell}

Junqing Pan ${ }^{1,2}$, Yanzhi Sun ${ }^{3}$, Wei Li², James Knight ${ }^{2} \&$ Arumugam Manthiram²

The automobile industry consumed 9 million metric tons of lead in 2012 for lead-acid batteries. Recycling lead from spent lead-acid batteries is not only related to the sustainable development of the lead industry, but also to the reduction of lead pollution in the environment. The existing lead pyrometallurgical processes have two main issues, toxic lead emission into the environment and high energy consumption; the developing hydrometallurgical processes have the disadvantages of high electricity consumption, use of toxic chemicals and severe corrosion of metallic components. Here we demonstrate a new green hydrometallurgical process to recover lead based on a hydrogen-lead oxide fuel cell. Highpurity lead, along with electricity, is produced with only water as the by-product. It has a $>99.5 \%$ lead yield, which is higher than that of the existing pyrometallurgical processes (95-97\%). This greatly reduces lead pollution to the environment.

\footnotetext{
${ }^{1}$ State Key Laboratory of Chemical Resource Engineering, Beijing University of Chemical Technology, Beijing 100029, China. ${ }^{2}$ Electrochemical Energy Laboratory, Materials Science and Engineering Program, The University of Texas at Austin, Austin, Texas 78712, USA. ${ }^{3}$ National Fundamental Research Laboratory of New Hazardous Chemicals Assessment and Accident Analysis, Beijing University of Chemical Technology, Beijing 100029, China.

Correspondence and requests for materials should be addressed to J.P. (email: japan@mail.buct.edu.cn) or to A.M. (email: rmanth@mail.utexas.edu).
} 
W ith the rapid developments in the automobile industry, the production of lead $(\mathrm{Pb})$-acid batteries as the automotive ignition power source has experienced enormous growth during the past few decades ${ }^{1}$. In 2012, 9 million metric tons of refined $\mathrm{Pb}$, which is about $85 \%$ of annual $\mathrm{Pb}$ production, was consumed globally for manufacturing $\mathrm{Pb}$-acid batteries for vehicles (http://www.ilzsg.org/static/statistics.aspx? from=1). Moreover, due to their low cost, $\mathrm{Pb}$-acid batteries are also a strong contender for grid storage of electricity produced by renewable energies such as solar and wind. An annual growth rate of $>6 \%$ is anticipated for the production of refined $\mathrm{Pb}$. Although there is no $\mathrm{Pb}$ pollution from using $\mathrm{Pb}$-acid batteries, their widespread use has caused a severe environmental problem due to toxic $\mathrm{Pb}$ emission and high energy consumption of the existing $\mathrm{Pb}$ pyrometallurgical processes for preparing metallic $\mathrm{Pb}^{2}$.

The raw materials (lead compounds) of the existing $\mathrm{Pb}$ pyrometallurgical processes are mainly obtained by extraction from natural lead oxide ores and pre-roasting oxidation of galena (lead sulphide $(\mathrm{PbS}) \rightarrow$ lead oxide $(\mathrm{PbO})$ ). As $\mathrm{Pb}$-acid batteries have been used worldwide in vehicles for decades, the raw materials are now mainly attained by recovering from waste $\mathrm{Pb}$ acid batteries via the desulfurization process of lead sulphate $\left(\mathrm{PbSO}_{4}\right)^{3,4}$ and the redox reaction of $\mathrm{Pb}$ and lead dioxide $\left(\mathrm{PbO}_{2}\right)^{5,6}$. The pyrometallurgical processes employ coke or carbon monoxide to reduce lead compounds at high temperature (about $1,000^{\circ} \mathrm{C}$ ) to gain the crude $\mathrm{Pb}$ with the release of $\mathrm{CO}_{2}$ gas ${ }^{7}$. $\mathrm{Pb}$ vapour/dust is also produced owing to its low melting point and escapes along with the exhaust gases into the atmosphere, known as $\mathrm{Pb}$ pollution ${ }^{7-9}$. High-purity $\mathrm{Pb}$ (99.99\%) is then obtained by refining the crude $\mathrm{Pb}$ using electrolytic refining or fire refining ${ }^{8}$. The whole process has a yield of $95-97 \%$ (refs 7,9,10).

Hydrometallurgical processes were proposed to eradicate the $\mathrm{Pb}$ pollution problem and obtain high-purity $\mathrm{Pb}$ (99.99\%) without the refining step ${ }^{8,11-20}$. These processes do not emit $\mathrm{Pb}$ vapour/dust to the environment due to their low operating temperature and lack of vapour production ${ }^{8,11}$; however, there are still many disadvantages, such as high electricity consumption, use of highly toxic hexafluorosilicic acid electrolyte and severe corrosion of metallic components ${ }^{12-21}$. As a result, these processes have not yet been adopted by the industry. It is an urgent requirement to develop a new green lead recovery process with lower energy consumption and without the use of toxic chemicals.
Herein we report a new green hydrometallurgical process for producing high-purity metallic $\mathrm{Pb}$ based on a specially designed $\mathrm{H}_{2}-\mathrm{PbO}$ fuel cell. The $\mathrm{PbO}$ serves as the $\mathrm{Pb}$ source and is prerefined in a hot sodium hydroxide $(\mathrm{NaOH})$ aqueous solution. This and the hydrogen gas undergo electro-reduction at the cathode and electro-oxidation at the anode in the fuel cell, respectively. The new process is energy-efficient and toxic-free (except for $\mathrm{PbO}$ and $\mathrm{Pb}$ ), and it produces only $\mathrm{Pb}$, water and electricity. It also does not involve $\mathrm{Pb}$ emission due to the low operating temperature of $60-100^{\circ} \mathrm{C}$. The $\mathrm{NaOH}$ concentration, temperature, $\mathrm{PbO}$ concentration and current density have been optimized to synthesize a dense, high-purity $\mathrm{Pb}$ (99.9992\%), qualified for $\mathrm{Pb}$-acid batteries with a high yield of $99.5-99.8 \%$, which is higher than that of existing pyrometallurgical processes (95-97\%), and greatly reduces lead pollution to the environment.

\section{Results}

$\mathrm{H}_{2}-\mathrm{PbO}$ fuel cell. Figure 1 illustrates the schematic of the new green hydrometallurgical process using the proposed $\mathrm{H}_{2}-\mathrm{PbO}$ fuel cell. Hydrogen gas is fed into the anode, where it undergoes electro-oxidation with the $\mathrm{OH}^{-}$ions to form water and releases electrons. The electrons pass through the external circuit, carry out electric work, and then arrive at the cathode. The refined $\mathrm{PbO}$ dissolved in heated aqueous $\mathrm{NaOH}$ forms $\mathrm{HPbO}_{2}^{-}$ions, which are then pumped into the cathode, where the $\mathrm{HPbO}_{2}^{-}$ions combine with the electrons from the anode and water to produce metallic $\mathrm{Pb}$ and $\mathrm{OH}^{-}$ions. The produced $\mathrm{OH}^{-}$ions combine with the $\mathrm{Na}^{+}$ions migrating from the anolyte through the sodium-ion exchange membrane to form $\mathrm{NaOH}$. The involved reactions including the complexation dissolution of $\mathrm{PbO}$ in $\mathrm{NaOH}$ are given below:

Anode: $\mathrm{H}_{2}+2 \mathrm{OH}^{-} \rightarrow 2 \mathrm{H}_{2} \mathrm{O}+2 \mathrm{e}^{-}$(electro-oxidation, $E^{\circ}=$ $-0.828 \mathrm{~V})$

Cathode: $\mathrm{PbO}(\mathrm{s})+\mathrm{OH}^{-} \rightarrow \mathrm{HPbO}_{2}^{-}$(complexation reaction) $\mathrm{HPbO}_{2}^{-}+2 \mathrm{e}^{-}+\mathrm{H}_{2} \mathrm{O} \rightarrow \mathrm{Pb}(\mathrm{s})+3 \mathrm{OH}^{-}$(electro-reduction, $\left.E^{\circ}=-0.531 \mathrm{~V}\right)$

The overall reaction of the fuel cell is

$\mathrm{H}_{2}+\mathrm{PbO}(\mathrm{s}) \rightarrow \mathrm{H}_{2} \mathrm{O}+\mathrm{Pb}(\mathrm{s})\left(\mathrm{E}^{\circ}=-0.531-(-0.828)=0.297 \mathrm{~V}\right)$

The positive standard potential of $0.297 \mathrm{~V}$ means that the reaction between $\mathrm{H}_{2}$ and $\mathrm{PbO}$ occurs spontaneously to produce $\mathrm{Pb}$, water and electricity. The experimental results show that the open-circuit voltage at room temperature is $0.226 \mathrm{~V}$, which is a

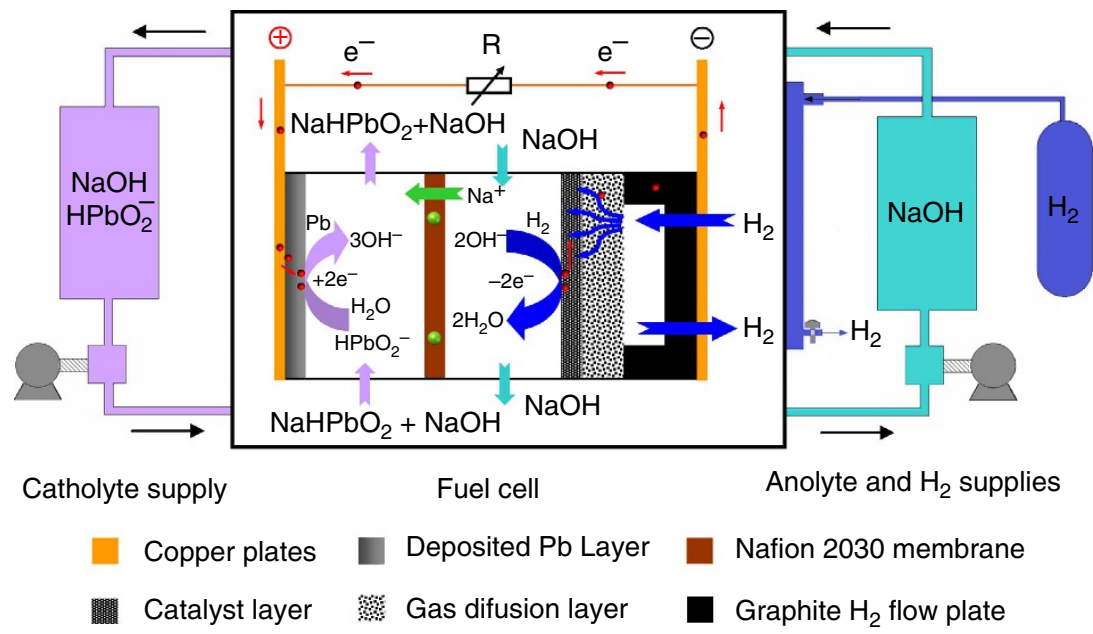

Figure 1 | Schematic of the $\mathbf{H}_{\mathbf{2}}$-PbO fuel cell. The Nafion 2030 membrane (DuPont) is an ion-selective, reinforced composite membrane designed to transport sodium ions and water while blocking $\mathrm{OH}^{-}$and $\mathrm{HPbO}_{2}^{-}$ions. The diffusion layer is a carbon paper (TGP-H-060, Toray) coated with carbon black (Vulcan $72 \mathrm{R}$, Cabot). The catalyst is carbon black-supported platinum nanoparticles (40 wt\% Pt/C, Johnson Matthey). 
little lower than the standard potential due to the non-standard conditions such as temperature, concentration and small polarization losses.

The complexation dissolution of $\mathrm{PbO}$ in a hot aqueous $\mathrm{NaOH}$ solution has a key role in making this process feasible. Although $\mathrm{PbO}$ is generally considered a basic metal oxide, it has a high solubility in concentrated aqueous $\mathrm{NaOH}$ solutions ${ }^{22}$. As shown in Fig. 2, the solubility of $\mathrm{PbO}$ strongly depends on temperature when the $\mathrm{NaOH}$ concentration is above $15 \%$. This characteristic of its solubility makes it possible to obtain a high concentration of high-purity $\mathrm{PbO}$ by a recrystallization process, which produces high-purity $\mathrm{Pb}$ at a fast reaction rate.

$\mathrm{PbO}$ recovery and purification. The $\mathrm{PbO}$ in this study was recovered from the spent lead paste (Zhejiang Huitong Group) from used $\mathrm{Pb}$-acid batteries by a desulfurization process of lead

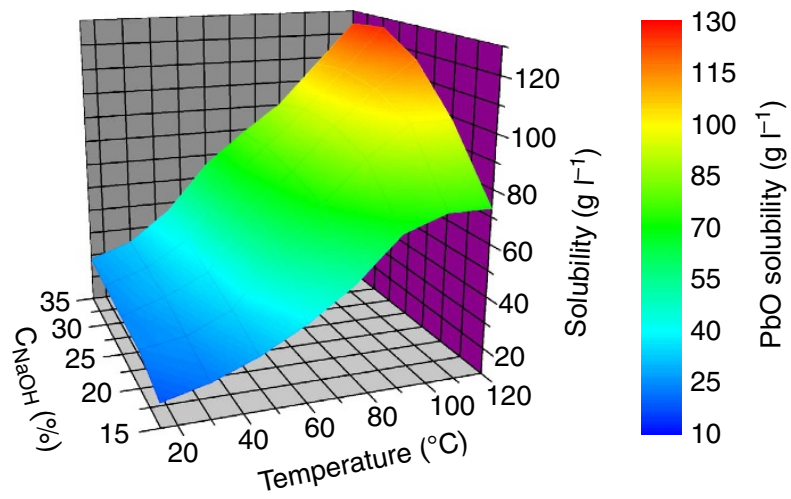

Figure 2 | Solubility of $\mathrm{PbO}$ versus temperature and $\mathrm{NaOH}$

concentration. The solubility is determined by a complexometric titration with EDTA.

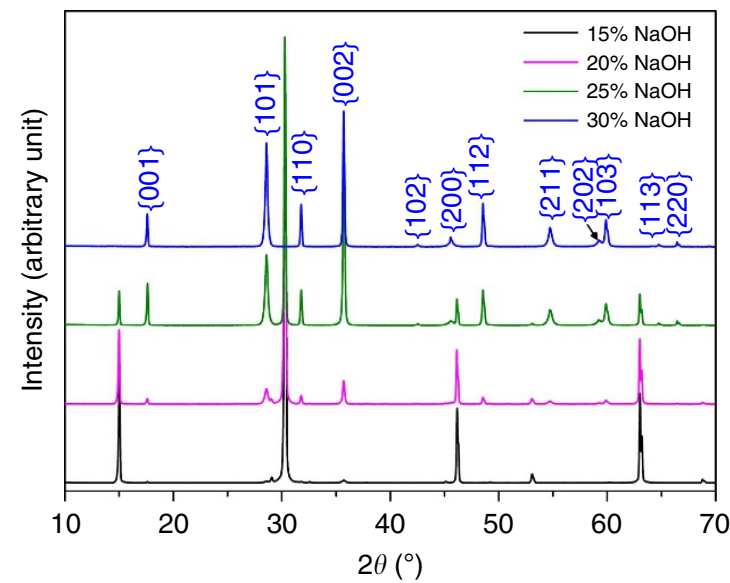

Figure 3 | XRD patterns of the $\mathbf{P b O}$ samples. The purified $\mathrm{PbO}$ samples were obtained from different concentrations of $\mathrm{NaOH}$ solutions: 15, 20, 25 and $30 \%$ sulphate and a redox reaction of $\mathrm{Pb}$ and $\mathrm{PbO}_{2}$ with a catalyst ${ }^{6}$. The actual recovery efficiency of $\mathrm{PbO}$ reaches $99.7 \%$.

The recovered $\mathrm{PbO}$ was purified by a recrystallization process, which is based on the strong temperature dependence of $\mathrm{PbO}$ solubility in a concentrated aqueous $\mathrm{NaOH}$ solution. The high purity of the obtained $\mathrm{PbO}$ ensures the quality of the electrolyte and the $\mathrm{Pb}$ synthesized by a $\mathrm{H}_{2}-\mathrm{PbO}$ fuel cell. Figure 3 compares the $\mathrm{XRD}$ patterns of the $\mathrm{PbO}$ samples purified by recrystallization in different concentrations of $\mathrm{NaOH}$. The location of the $\{001\}$ peak was used to identify the polymorph of the $\mathrm{PbO}$ phase, that is, massicot or litharge. It was found that the $\mathrm{PbO}$ obtained from a low concentration of $\mathrm{NaOH}(15 \%)$ is massicot (PDF no. 00-0050570 ) and from a high concentration $(30 \%)$ is litharge (PDF no. 00-005-0561). The $\mathrm{PbO}$ obtained from $\mathrm{NaOH}$ concentrations of $15-30 \%$ is a mixture of massicot and litharge. It was also found that the $\mathrm{PbO}$ obtained in $30 \% \mathrm{NaOH}$ has the main peak located at about $35.7^{\circ}$, which means that the crystalline $\mathrm{PbO}$ prefers to grow along with $<002>$ direction.

All purified $\mathrm{PbO}$ samples show irregular shapes with sizes in the range of $10-15 \mu \mathrm{m}$ (Supplementary Fig. S1). Compared with the desulfurized $\mathrm{PbO}$ from the spent lead-acid batteries, the inductively coupled plasma (ICP) analysis shows that the purified $\mathrm{PbO}$ samples have much lower impurities of other metals (Table 1). These high-purity $\mathrm{PbO}$ samples are suitable for the synthesis of high-quality $\mathrm{Pb}$.

Synthesis of metallic $\mathbf{P b}$. The first trial to obtain $\mathrm{Pb}$ was carried out with an anolyte of $20 \% \mathrm{NaOH}$ and a catholyte of $20 \%$ $\mathrm{NaOH}+0.1 \mathrm{moll}^{-1} \mathrm{PbO}$ at a current density of $5 \mathrm{~mA} \mathrm{~cm}^{-2}$ at room temperature. The XRD pattern in Fig. 4a confirms that the obtained grey material on the copper cathode is metallic $\mathrm{Pb}$ with some $\mathrm{PbO}$ impurities. The sample is made of loose particles as shown in the field emission-scanning electron microscopy (FESEM) image in Fig. 4b. Compared with bulk dense $\mathrm{Pb}$, this particulate $\mathrm{Pb}$ has a larger surface area and is thus easier to oxidize in air in storage and in the melting process to make lead ingots. This is why some $\mathrm{PbO}$ co-exists as shown by the XRD pattern in Fig. 4a. The product is also porous with a large volume, which is not desirable for transport and storage.

To obtain high-purity $\mathrm{Pb}$ with a dense structure, fast reaction rate and high yield, three factors, the $\mathrm{NaOH}$ concentration (same at the anode and cathode before operation, 15-35\%), temperature $\left(30-105^{\circ} \mathrm{C}\right)$ and $\mathrm{PbO}$ concentration $\left(0.05-0.4 \mathrm{moll}^{-1}\right)$, were systematically investigated. The details are presented in Supplementary Notes 1,2,3, respectively. A brief description is given as follows. A low $\mathrm{NaOH}$ concentration is favourable to the formation of a dense structure (Supplementary Fig. S2) and the kinetics of the electro-reduction reaction of $\mathrm{Pb}^{2+}$ (Supplementary Fig. S3). As for the temperature effects, an intermediate temperature is helpful to form a dense structure (Supplementary Fig. S4). A high temperature increases the kinetics of the electroreduction reaction of $\mathrm{Pb}^{2}+$ (Supplementary Fig. S5) and the hydrogen electro-oxidation reaction (Supplementary Fig. S6). A comparison between the kinetics of both reactions (Supplementary Fig. S7) reveals that the $\mathrm{H}_{2}-\mathrm{PbO}$ fuel cell performance is limited by the $\mathrm{Pb}^{2}+$ electro-reduction. Similar to the temperature

Table 1 | ICP analysis results of the PbO samples.

\begin{tabular}{lcccccccc} 
PbO & $\mathbf{A g}, \%$ & $\mathbf{C u}, \%$ & $\mathbf{B i}, \%$ & As, \% & Sb, \% & Sn, \% & Zn, \% & Fe, \% \\
\hline a & 0.0006 & 0.0022 & 0.0016 & 0.0007 & 0.0035 & 0.0019 & 0.0002 & 0.0045 \\
b & 0.0002 & 0.0001 & 0.0003 & 0.00009 & 0.0006 & 0.0003 & 0.00005 & 0.0003 \\
\hline
\end{tabular}

a, before recrystallization; b, after recrystallization in $25 \% \mathrm{NaOH}$; ICP, inductively coupled plasma. 
effect, an intermediate $\mathrm{PbO}$ concentration helps form a dense structure (Supplementary Fig. S8) and a high $\mathrm{PbO}$ concentration promotes the kinetics of the electro-reduction reaction of $\mathrm{Pb}^{2+}$
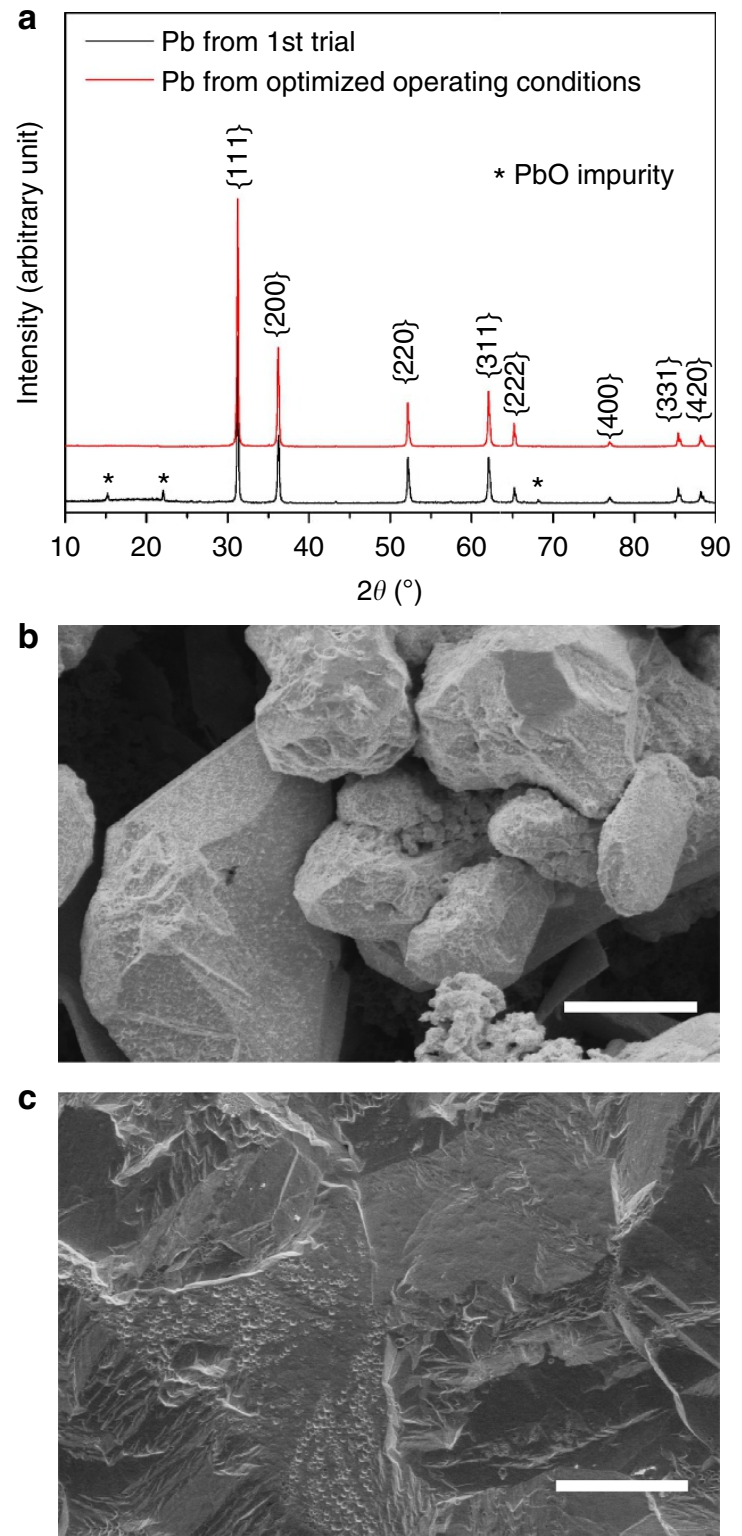

Figure 4 | $\mathbf{P b}$ samples produced in the $\mathbf{H}_{\mathbf{2}}-\mathbf{P b O}$ fuel cell. (a) X-ray diffraction patterns of the $\mathrm{Pb}$ samples produced initially and under optimized conditions later. (b) FE-SEM image of the $\mathrm{Pb}$ sample produced initially. (c) FE-SEM image of the $\mathrm{Pb}$ produced under optimized conditions. Scale bar, $100 \mu \mathrm{m}$.
(Supplementary Fig. S9). All three factors do not significantly affect the current efficiencies of the $\mathrm{Pb}$ electro-deposition, as shown in Supplementary Tables S1,S2,S3, respectively. Considering the morphology of the produced $\mathrm{Pb}$ (dense structure), the kinetics of the $\mathrm{Pb}$ electro-deposition reaction (low overpotential and fast reaction) and the current efficiency, the optimized $\mathrm{NaOH}$ concentration, temperature and $\mathrm{PbO}$ concentration were determined to be $20 \%, 85^{\circ} \mathrm{C}$ and $0.3 \mathrm{moll}^{-1}$, respectively.

The $\mathrm{Pb}$ prepared under the optimized conditions has a dense structure (FE-SEM image in Fig. 4c) and thus has no significant oxidation, as confirmed by the XRD pattern in Fig. 4a. The ICP analysis in Table 2 indicates that the purity of the electrodeposited $\mathrm{Pb}$ is $99.9992 \%$, which is much higher than the $1 \#$ standard $\mathrm{Pb}(\mathrm{GB} / \mathrm{T}$ 468-2005, Chinese standard, 99.994\%) and PB990R grade Pb (EN 12659-1999, European standard, 99.99\%). This ultra-high-purity $\mathrm{Pb}$ is a superior material for the manufacture of high-quality $\mathrm{Pb}$-acid batteries with a longer cycle life. In addition, all of the current efficiencies are greater than 99.5\%, indicating a very high selectivity of the $\mathrm{Pb}$ reduction reaction at the cathode.

Figure 5a shows the polarization curve and surface power curve of the $\mathrm{H}_{2}-\mathrm{PbO}$ fuel cell operated under the optimized conditions. The $\mathrm{Pb}$ samples prepared at 20,40,60 and $80 \mathrm{~mA} \mathrm{~cm}^{-2}$ have dense structures as shown by the FE-SEM images (Supplementary Fig. S10), suggesting that the current density does not affect the surface morphology of the $\mathrm{Pb}$ samples. Additionally, the current density also does not affect the current efficiency (Supplementary Table S4). Therefore, the fuel cell can operate at $40 \mathrm{~mA} \mathrm{~cm}^{-2}$ to achieve a maximum electric surface power density of $5.5 \mathrm{~mW} \mathrm{~cm}^{-2}$ at $80 \mathrm{~mA} \mathrm{~cm}^{-2}$ and a high production rate of $\mathrm{Pb}$. As shown in Fig. 5b, the reduction of $\mathrm{PbO}$ can be accomplished in 14.02, 7.02, 4.69 and $3.45 \mathrm{~h}$ at 20,40, 60 and $80 \mathrm{~mA} \mathrm{~cm}^{-2}$, respectively. According to Faraday's law, the reaction conversions of $\mathrm{PbO}$ to $\mathrm{Pb}$ were $99.6 \%, 99.8 \%, 99.7 \%$ and $99.3 \%$. The catholyte thus had a very small amount of unreacted $\mathrm{PbO}$ residue. This residual $\mathrm{PbO}$ can be further reduced by an ion exchange process or electrolysis until it does not affect the recyclability of the reacted catholyte for preparing the anolyte.

\section{Discussion}

This new green $\mathrm{Pb}$ hydrometallurgical process employing an $\mathrm{H}_{2}-$ $\mathrm{PbO}$ fuel cell eliminates $\mathrm{Pb}$ pollution and significantly reduces energy consumption, which are the two major issues for the existing $\mathrm{Pb}$ pyrometallurgical processes and other developing pyrometallurgical and hydrometallurgical processes. A detailed comparison is given in Table 3. Unlike the pyrometallurgical processes, this new process has no $\mathrm{Pb}$ vapour or slag released to the environment, leading to an annual reduction of $12,000-$ 20,000 metric tons of $\mathrm{Pb}$ (vapor/dust and slag) emission to the environment for a plant with an annual output of 400,000 metric tons of $\mathrm{Pb}$. Furthermore, compared with other hydrometallurgical processes, this new process does not employ any toxic chemicals,

Table 2 | Comparison of $\mathrm{Pb}$ compositions.

Pb samples

Composition (\%)

\begin{tabular}{|c|c|c|c|c|c|c|c|c|c|c|c|}
\hline & \multirow[b]{2}{*}{$\mathbf{P b}, \geq$} & \multicolumn{10}{|c|}{ Impurities, $\leq \times 10^{-4}$} \\
\hline & & Ag & $\mathrm{Cu}$ & Bi & As & Sb & Sn & Zn & $\mathbf{F e}$ & Cd & $\mathbf{N i}$ \\
\hline $1 \# \mathrm{~Pb}$ & 99.994 & 8 & 10 & 40 & 5 & 8 & 5 & 4 & 5 & / & / \\
\hline PB990R Pb & 99.99 & 15 & 5 & 100 & 5 & 5 & 5 & 2 & / & 2 & 2 \\
\hline Electro-deposited Pb & 99.9992 & 1 & 0.8 & 2 & 0.5 & 1.5 & 1 & 0.3 & 0.4 & 0.2 & 0.1 \\
\hline
\end{tabular}

The 1 \# standard $\mathrm{Pb}$ (GB/T 468-2005, Chinese standard), PB990R Pb (EN 12659-1999, European standard) and ICP analysis results of the Pb obtained under optimized operating conditions of 20\% $\mathrm{NaOH}, 0.3 \mathrm{moll}^{-1} \mathrm{PbO}, 40 \mathrm{~mA} \mathrm{~cm}{ }^{-2}$ and $85^{\circ} \mathrm{C}$ are listed. 
such as hydrofluoric acid. Regarding the energy consumption, this new process needs about $1 / 2$ or $1 / 3$ of the energy used for the existing pyrometallurgical or other hydrometallurgical processes, respectively. This new process, as a fuel cell, also produces electricity (5.3-45.5 Wh per kg of $\mathrm{Pb}$ ) depending on the current density, and can also be applied for preparation of other metals such as copper, silver, antimony and nickel. To accomplish this, two main conditions need to be satisfied. First, the raw materials should dissolve in a basic solution. Second, the reduction potential of the metal ions should be higher than that of the hydrogen ion.
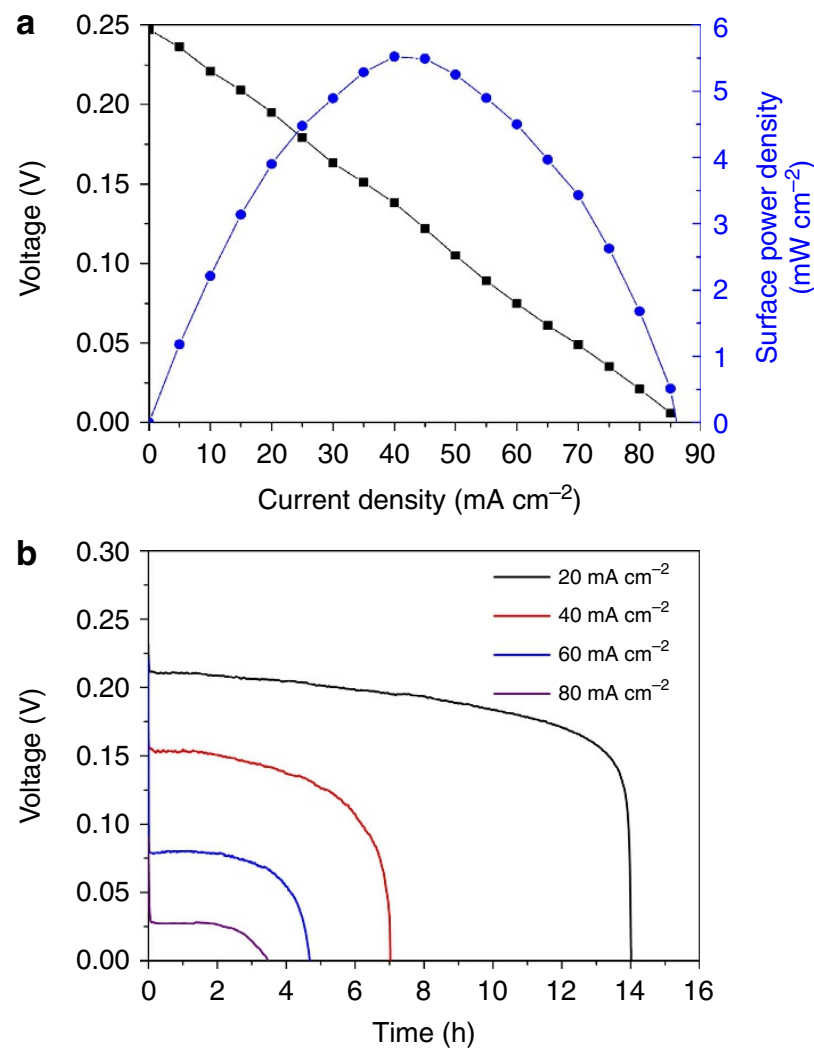

Figure 5 | Characterizations of the new lead hydrometallurgical process. (a) Polarization curve and specific power curve of the $\mathrm{H}_{2}-\mathrm{PbO}$ fuel cell.

(b) Voltage versus time curves at different current densities of the $\mathrm{H}_{2}-\mathrm{PbO}$ fuel cell.

\section{Methods}

General procedure for recovery of $\mathrm{PbO}$ from the spent lead paste. The spent lead paste from used $\mathrm{Pb}$-acid batteries was supplied by Zhejiang Huitong Group, China. Its main ingredients are $12.6 \% \mathrm{~Pb}, 15.3 \% \mathrm{PbO}, 26.8 \% \mathrm{PbO}_{2}$ and $44.2 \%$ $\mathrm{PbSO}_{4}$, and the remainder (1.1\%) is $\mathrm{H}_{2} \mathrm{O}$ and $\mathrm{H}_{2} \mathrm{SO}_{4}$. The recovery of $\mathrm{PbO}$ from the spent lead paste employs four processes ${ }^{6}$ : desulfurization, redox, synchronizing dissolution and crystallization. The involved chemical reactions and detailed descriptions are given below.

Desulfurization process. $\mathrm{PbSO}_{4}(\mathrm{~s})+2 \mathrm{NaOH}(\mathrm{aq})=\mathrm{PbO}(\mathrm{s})+\mathrm{H}_{2} \mathrm{O}+\mathrm{Na}_{2} \mathrm{SO}_{4}(\mathrm{~s})$ $\left(30^{\circ} \mathrm{C}\right)$. The spent lead paste $(100 \mathrm{~g})$ was added to $10 \% \mathrm{NaOH}(120 \mathrm{ml})$ for the desulfurization process to convert $\mathrm{PbSO}_{4}$ to $\mathrm{PbO}$. The reaction temperature was controlled at $30^{\circ} \mathrm{C}$ and the paste was stirred at 150 r.p.m. for $10 \mathrm{~min}$.

Redox process. $\mathrm{Pb}(\mathrm{s})+\mathrm{PbO}_{2}(\mathrm{~s})+2 \mathrm{NaOH}(\mathrm{aq})=2 \mathrm{NaHPbO}_{2}(\mathrm{aq})\left(115^{\circ} \mathrm{C}\right)$. The obtained sample A (a mixture of $\mathrm{Pb}, \mathrm{PbO}$ and $\mathrm{PbO}_{2}$ ) from the desulfurization process was filtered with a Buchner funnel and washed with deionized water. Sample A was carefully transferred to the reactor containing $30 \% \mathrm{NaOH}$ saturated with $30 \mathrm{gl}^{-1} \mathrm{PbO}$ at room temperature. A calculated amount of $\mathrm{Pb}$ powder $(10.6 \mathrm{~g}$, 120 mesh) was supplied as the reductant and $\mathrm{Na}_{3} \mathrm{SbO}_{3}(0.15 \mathrm{~g})$ was added as the catalyst for the redox reaction of $\mathrm{Pb}$ and $\mathrm{PbO}_{2}$. The reaction was controlled at $115^{\circ} \mathrm{C}$ and the reaction paste was stirred at 300 r.p.m. for $3 \mathrm{~h}$.

Synchronizing dissolution process. $\mathrm{PbO}(\mathrm{s})+\mathrm{NaOH}(\mathrm{aq})=\mathrm{NaHPbO}_{2}(\mathrm{aq})$ $\left(115^{\circ} \mathrm{C}\right)$. During the redox process, the $\mathrm{PbO}$ of sample A was also synchronization dissolved in the $\mathrm{NaOH}$ solution at $115^{\circ} \mathrm{C}$.

Crystallization process. $\mathrm{NaHPbO}_{2}(\mathrm{aq})=\mathrm{NaOH}(\mathrm{aq})+\mathrm{PbO}(\mathrm{s})\left(25^{\circ} \mathrm{C}\right)$. The previously obtained $\mathrm{NaHPbO}_{2} / \mathrm{NaOH}$ solution was immediately filtered and slowly cooled to room temperature with continuous stirring. During the cooling process, kermesinus $\mathrm{PbO}$ slowly precipitates from the solution. It was filtered by a G-2 sintered glass filter, washed with deionized water and dried at $60^{\circ} \mathrm{C}$. The final recovered $\mathrm{PbO}$ weighed $97.2 \mathrm{~g}$, and thus the $\mathrm{PbO}$ recovery efficiency was $99.7 \%$.

Determination of $\mathrm{PbO}$ solubility. The recovered $\mathrm{PbO}$ was purified by a recrystallization process. The solubility of the purified $\mathrm{PbO}$ in $\mathrm{NaOH}$ aqueous solutions was determined by a complexometric titration with EDTA, described as follows. An excess of $\mathrm{PbO}$ was added to a $\mathrm{NaOH}$ solution, which was then stirred and heated to the temperature, at which the solubility will be determined. The solution was kept stirring at that temperature for $5 \mathrm{~min}$ and subsequently stayed still for $10 \mathrm{~min}$. An aliquot of this $\mathrm{PbO} / \mathrm{NaOH}$ solution $(0.10 \mathrm{ml})$ was quickly transferred to a stirring $\mathrm{HNO}_{3}$ solution $\left(10 \mathrm{ml}, 1 \mathrm{moll}^{-1}\right)$. After that, an extra amount $(1.5 \times$ stoichiometric amount) hexamethylenetetramine was added to neutralize the $\mathrm{HNO}_{3}$. The solution was finally titrated by a standard EDTA solution $\left(0.020 \mathrm{moll}^{-1}\right)$ with xylenol orange as the indicator.

$\mathbf{H}_{2}-\mathbf{P b O}$ fuel cell and synthesis of $\mathbf{P b}$. The $\mathrm{H}_{2}-\mathrm{PbO}$ fuel cell consisted of an anode of $2 \times 2 \mathrm{~cm}^{2}$ carbon paper (TGP-H-060, Toray) with a carbon black (Vulcan 72R, Cabot) loading of $0.5 \mathrm{mg} \mathrm{cm}^{-2}$ and a Pt catalyst loading of $1.0 \mathrm{mg} \mathrm{cm}^{-2}$ $(40 \mathrm{wt} \% \mathrm{Pt} / \mathrm{C} \text {, Johnson Matthey) })^{23}$, a cathode of $2 \times 2 \mathrm{~cm}^{2}$ high-purity copper plate, Nafion 2030 sodium ion-selective membrane (DuPont), anolyte of aqueous $\mathrm{NaOH}$ solution $\left(15-35 \%, 60 \mathrm{ml} \mathrm{min}^{-1}\right)$ and catholyte of aqueous $\mathrm{NaOH}-\mathrm{PbO}$ (15-35\% $\mathrm{NaOH}$ and $0.05-0.4 \mathrm{~mol} \mathrm{l}^{-1} \mathrm{PbO}, 60 \mathrm{ml} \mathrm{min}^{-1}$ ) solution. The $\mathrm{NaOH}$ concentrations at the anode and cathode were kept the same before operation. The

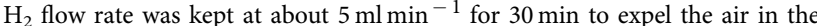

Table 3 | Comparison of three $\mathrm{Pb}$ metallurgical processes.

\begin{tabular}{|c|c|c|c|}
\hline Item & Pyrometallurgical processes & Hydrometallurgical processes & $\mathrm{H}_{2}-\mathrm{PbO}$ fuel cell \\
\hline Temperature, ${ }^{\circ} \mathrm{C}$ & $700-1,100$ & $20-100$ & $20-100$ \\
\hline Yield, \% & 95 & $>97$ & $>99.5$ \\
\hline $\mathrm{Pb}$ purity, \% & $97-99$ & 99.99 & 99.9992 \\
\hline $\begin{array}{l}\text { Refining energy consumption, } \\
\mathrm{kW} \text { h per metric ton } \mathrm{Pb}\end{array}$ & $120-130$ & 0 & 0 \\
\hline Pollution & $\mathrm{Pb}$ vapour, dust and slag; HF from refining & HF and so on & None \\
\hline Energy price & 0.28 US $\$ \mathrm{~kg}_{\text {coal }}^{-1} 0.12$ US $\$ \mathrm{kWh}^{-1}$ & 0.12 US $\$ \mathrm{kWh}^{-1}$ & 3.1 US $\$ \mathrm{~kg}_{\mathrm{H} 2} 1$ \\
\hline Energy cost, US \$ per metric ton $\mathrm{PbO}$ & $47.3-63.8$ & 78- 112 & $28.5^{\star}$ \\
\hline
\end{tabular}


hydrogen channel before operation. The valve at the hydrogen channel outlet was closed during the experiments. The pressure of $\mathrm{H}_{2}$ in the channel was $0.1 \mathrm{MPa}$. To reduce the formation of $\mathrm{Pb}$ dendrites, DPE-3 (electroplating additive, Wuhan Yangtze Plating Additives Plant) was added as an additive into the catholyte with a concentration of $6 \mathrm{mll}^{-1}$. Two $\mathrm{Hg} / \mathrm{HgO}$ reference electrodes were used to control the potentials of the anode and cathode. A battery test station (LAND 2001A, Wuhan LAND Electronics) was used to run the fuel cell in constant current mode. The electrochemical measurements of the fuel cell were performed on a CSU-300 electrochemical workstation (Wuhan Corrtest Instrument).

Characterization of the synthesized $\mathbf{P b}$. For the characterization of the $\mathrm{Pb}$ product, the cathode with produced $\mathrm{Pb}$ plate was taken out from the system, washed with deionized water, vacuum dried at $60^{\circ} \mathrm{C}$ for $3 \mathrm{~h}$ and then stored under argon to avoid oxidation in air. The mass of $\mathrm{Pb}$ was obtained by subtracting the $\mathrm{Cu}$ cathode from the total mass of the $\mathrm{Cu}$ cathode with $\mathrm{Pb}$. The $\mathrm{Pb}$ surface morphology was examined by an FE-SEM (Hitachi S4700). The composition of the $\mathrm{Pb}$ was measured with an ICP analyzer (Agilent 7700). The XRD patterns of the $\mathrm{Pb}$ samples were recorded on a Rigaku D/max2500VB2 +/PC diffractometer with $\mathrm{Cu}$ $\mathrm{K} \alpha$ radiation $(\lambda=0.15418 \mathrm{~nm}, 40 \mathrm{kV}, 200 \mathrm{~mA})$.

\section{References}

1. Roberts, H. Changing patterns in global lead supply and demand. J. Power Sources 116, 23-31 (2003).

2. Eckel, W. P., Rabinowitz, M. B. \& Foster, G. D. Investigation of unrecognized former secondary lead smelting sites: confirmation by historical sources and elemental ratios in soil. Environ. Pollut. 117, 273-279 (2002).

3. Zhu, X. et al. Preparation of basic lead oxide from spent lead acid battery paste via chemical conversion. Hydrometallurgy 117-118, 24-31 (2012).

4. Sonmez, M. S. \& Kumar, R. V. Leaching of waste battery paste components. Part 1: Lead citrate synthesis from $\mathrm{PbO}$ and $\mathrm{PbO}_{2}$. Hydrometallurgy 95, 53-60 (2009).

5. Pan, J. et al. A new atom-economical method for the recovery of wasted leadacid batteries in the production of lead oxide, CN Patent, 201310084392.X (2013)

6. Pan, J., Song, S., Sun, Y. \& Niu, Y. A recycling method of waste lead acid batteries for the directly manufacturing of high purity lead oxide. CN Patent, 201210535154.1 (2012).

7. Rabah, M. A. \& Barakat, M. A. Energy saving and pollution control for short rotary furnace in secondary lead smelters. Renew. Ener. 23, 561-577 (2001).

8. Ellis, T. W. \& Mirza, A. H. The refining of secondary lead for use in advanced lead-acid batteries. J. Power Sources 195, 4525-4529 (2010).

9. Yang, K. \& Shi, Z. Energy consumption analysis of oxygen bottom-blown converter melting first crude lead. Ener. Metallurg. Industry 29, 14-16 (2010).

10. He, J. The application prospect of KIVCET direct lead smelting. Hunan Nonferrous Metals 27, 20-23 (2011).

11. Andrews, D., Raychaudhuri, A. \& Frias, C. Environmentally sound technologies for recycling secondary lead. J. Power Sources 88, 124-129 (2000).

12. Ferracin, L. C. et al. Lead recovery from a typical Brazilian sludge of exhausted lead-acid batteries using an electrohydrometallurgical process. Hydrometallurgy 65, 137-144 (2002).

13. Expósito, E., Iniesta, J., González-García, J., Montiel, V. \& Aldaz, A. Lead electrowinning in an acid chloride medium. J. Power Sources 92, 260-266 (2001).
14. Ginatta, M. V. Method for the electrolytic production of lead. US Patent, 4,451,340 (1984).

15. Olper, M. \& Fracchia, P. Hydrometallurgical process for an overall recovery of the components of exhausted lead-acid batteries. US Patent, 4,769,116 (1988).

16. Prengaman, R. D. \& McDonald, H. B. Method of recovering lead values from battery sludge. US Patent, 4,229,271 (1980).

17. Olper, M. \& Fracchia, P. Hydrometallurgical process for recovering in pure metal form all the lead contained in the active mass of exhausted batteries. US Patent, 4,927,510 (1990)

18. Olper, M. \& Fracchia, P. Process for producing electrolytic lead and elemental sulfur from galena. US Patent, 5,039,337 (1991).

19. Cole, J. E. R., Lee, A. Y. \& Paulson, D. L. Electrowinning of lead from $\mathrm{H}_{2} \mathrm{SiF}_{6}$ solution. US Patent, 4,272,340 (1981)

20. Prengaman, R. D. \& MaDonald, H. B. Process for reducing lead peroxide formation during lead electrowinning. US Patent, 4,230,545 (1980).

21. Pan, J. et al. A clean lead recovery method by solid-liquid electrolytic process. CN Patent, 201010184958.2 (2010).

22. Pan, J., Zhang, C., Sun, Y. b., Wang, Z. \& Yang, Y. A new process of lead recovery from waste lead-acid batteries by electrolysis of alkaline lead oxide solution. Electrochem. Commun. 19, 70-72 (2012).

23. Li, W. \& Lane, A. M. Investigation of Pt catalytic effects on carbon support corrosion of the cathode catalyst in PEM fuel cells using DEMS spectra. Electrochem. Commun 11, 1187-1190 (2009).

\section{Acknowledgements}

The work at Beijing University of Chemical Technology (BUCT, China) was supported by the State Key Program of National Natural Science of China (no. 21236003) and National Natural Science Foundation of China (no. 21006003). The work at the University of Texas at Austin (UT-Austin) was supported by the US Department of Energy, Office of Basic Energy Sciences, Division of Materials Sciences and Engineering under award number DE-SC0005397.

\section{Author contributions}

J.P. proposed the concept, designed and performed the experiments, and supervised the research work at BUCT. Y.S. designed and performed the experiments at BUCT. W.L. contributed to the concept and designed and performed the preliminary experiments at UT-Austin. J.K. performed the preliminary experiments at UT. A.M. supervised the research work at UT-Austin. All five authors contributed to the writing of the manuscript. J.P. worked at UT during August 2010-September 2011.

\section{Additional information}

Supplementary Information accompanies this paper at http://www.nature.com/ naturecommunications

Competing financial interests: The authors declare no competing financial interests.

Reprints and permission information is available online at http://npg.nature.com/ reprintsandpermissions/

How to cite this article: Pan, J. et al. A green lead hydrometallurgical process based on a hydrogen-lead oxide fuel cell. Nat. Commun. 4:2178 doi: 10.1038/ncomms3178 (2013). 